\title{
THE CISG AND COMMON LAW COURTS: IS THERE REALLY A PROBLEM?
}

\author{
Henning Lutz
}

The United Nations Convention on Contracts for the International Sale of Goods (CISG) is generally perceived as a successful example of unified law with 62 contracting states so far. However, this impressive number has not resulted in an evenly-spread acceptance of the CISG worldwide. The scarcity of CISG-related case law from common law countries has led to the assumption that common law jurisdictions have specific issues with the application of the CISG. This article examines the various explanations for this phenomenon that have been put forward so far, primarily through an analysis of case law. The article disproves the contention that common law jurisdictions, when interpreting the CISG, employ a narrow approach, persistently adhere to common law specific concepts, or are generally reluctant to refer to scholarly writings. It emerges that the CISG is a well-known feature in most common law courtrooms, applied by judges with growing skill and prudence. The article concludes that often common law lawyers are more ignorant and unfamiliar with the CISG than judges and appeals to them to improve their knowledge by taking advantage of the numerous sources of information about the CISG.

\section{INTRODUCTION}

The United Nations Convention on Contracts for the International Sale of Goods (CISG) and the process by which it was created have widely been perceived as a benchmark for the successful unification of commercial law in the post-war era. ${ }^{1}$ In fact, the CISG has so far drawn the impressively large number of 62 states to join its regime, accounting for two-thirds of all world trade. ${ }^{2}$ However, the low number of reported decisions from common law countries has induced

* $\quad$ Submitted as part of the LLM programme at Victoria University of Wellington (supervisor: Dr Petra Butler).

1 Harold S Burman "Building on the CISG: International Commercial Law Developments and Trends for the 2000's" (1998) $17 \mathrm{~J}$ L and Commerce 355; other commentators have called the CISG a "quantum leap", a "new legal lingua franca", a "milestone" and "arguably the greatest legislative achievement aimed at harmonizing private commercial law": see Kevin Bell "The Sphere of Application of the Vienna Convention on Contracts for the International Sale of Goods" (1996) Pace Int'l L Rev 237, 238.

2 As at 21 May 2004. 
various authors to find special issues that common law jurisdictions allegedly have with the application of the CISG. ${ }^{3}$

For illustration purposes these scholars have primarily referred to early, and sometimes obscure or even outdated United States court decisions. ${ }^{4}$ Today, the United States CISG case law, after an initial dry spell of ten years, is now by far the most developed and thoroughly examined amongst the common law member states to the CISG. ${ }^{5}$ Given this phenomenon and the previous lack of attention to other common law jurisdictions, the time seems ripe for a revision of the alleged mismatch between the CISG and the common law. To that end, this article will also focus on the developments in the common law jurisdictions of Australia, New Zealand and the United Kingdom.

The article will reveal that the still significant disparity in numbers of cases reported in civil and in common law countries, although undeniable, does not reflect a specific, inherent incompatibility of the common law with the CISG. Some of the alleged issues have been or are about to be overcome, others are founded in ignorance and neglect, neither of which is specifically a common law vice.

Part II briefly sketches the historical background of the CISG to give an overall perspective of the drafting process leading to its adoption and the involvement of common law countries. Subsequent sections will focus on the specific issues of the CISG in regard to common law jurisdictions as claimed by several critics. The article will evaluate the different contentions and derive further implications from them with reference to case law, particularly from the common law jurisdictions of Australia and New Zealand. It concludes that the CISG's alleged problems in common law jurisdictions do not pose insurmountable obstacles to the future development of CISG case law in these countries.

\section{HISTORICAL BACKGROUND OF THE CISG}

An informed appraisal of the alleged specific issues of common law jurisdictions with the CISG requires some basic historical knowledge about the genesis of the Convention.

As early as the 1920s Western European countries began formulating ideas for a uniform international sales regime which would facilitate the ever-growing flows of international trade. In

3 Monica Kilian "CISG and the Problem with Common Law Jurisdictions" (2001) 10 J Transnat'l L and Policy 217; John E Murray "The Neglect of CISG: A Workable Solution" (1998) 17 J L and Commerce 365; Jacob S Ziegel "The Future of the International Sales Convention from a Common Law Perspective" (2000) 6 NZBLQ 336.

4 See for example Kilian, above n 3, 217 and 227.

529 out of 52 cases in total were decided between 1998 and 2003. See CISG Case database of the Pace University School of Law, New York <http://www.cisg.law.pace.edu/cisg/text/casecit.html> (last accessed 21 May 2004). 
1929 the newly created International Institute for the Unification of Private Law (UNIDROIT), ${ }^{6}$ represented by French, German, English and Scandinavian scholars, began to draft a uniform law for the international sale of goods. The then prevailing credo of legal positivism led to the common understanding that the envisaged uniform rules were to be prepared in the form of a binding instrument. ${ }^{7}$

In 1964 a UNIDROIT conference at The Hague adopted two conventions: the Convention relating to a Uniform Law of International Sales (ULIS) and the Convention relating to a Uniform Law on the Formation of Contracts for the International Sale of Goods (ULF), ("the Hague Conventions"). ${ }^{8}$ From the very beginning, the Hague Conventions lacked widespread acceptance because they were perceived mainly as a creation of Western European civil law legal scholarship, neglecting the common law and other legal traditions. ${ }^{9}$ In fact, the United Kingdom was the only common law jurisdiction to ever ratify the Hague Conventions. However, its ratification had limited significance due to a special reservation made by the United Kingdom according to which the conventions would only apply where the parties themselves had adopted the conventions as the laws of their contract. ${ }^{10}$ The other leading common law jurisdiction, the United States, had neither participated in the drafting process nor ever ratified the Hague Conventions.

The failure of the Hague Conventions led to the establishment of the United Nations Commission on International Trade Law (UNCITRAL) in 1966. UNCITRAL's main object was to draft an international treaty for the sale of goods that would be more universally accepted "by countries of different legal, social and economic systems". ${ }^{11}$ To avoid further complaints about misrepresentation UNCITRAL and the Working Group that took over the drafting were carefully composed of members from the most diverse range of countries. The common law was well represented by Australia, Canada, New Zealand, the United Kingdom and the United States. ${ }^{12}$ The drafting, based on the Hague Conventions, led to the adoption of a single Draft Convention on

6 UNIDROIT is an acronym of the French name of the Institute, the "Institut International pour l'Unification du Droit Privé".

7 Michael Joachim Bonell "The UNIDROIT Principles of International Commercial Contracts and CISG Alternatives or Complementary Instruments?" (1996) 26 Uniform L Rev 26, 27.

8 See UNIDROIT < http://www.unidroit.org> (last accessed 21 May 2004).

9 Only 28 states had attended the Hague Conference in 1964, 19 of them from Western Europe.

10 ULIS, Art V and ULF, Annex II Art1; Gambia made the same reservations.

11 Report of the United Nations Commission on International Trade Law on the Work of its Second Session (1969) I UNCITRAL Yearbook 99-100, para 38, 3(a).

12 General Assembly Resolution 2205 (XXI), above, para II 1, 65. 
Contracts for the International Sale of Goods by UNCITRAL in $1978 .{ }^{13}$ Two years later, at a United Nations conference in Vienna, the participating states approved the present text of the CISG. After the ratifications of the United States, China, and Italy exceeded the required threshold of ten member states, the CISG entered into force on 1 January $1988 .{ }^{14}$

\section{ISSUES SPECIFIC TO THE COMMON LAW}

One might believe that the involvement in the drafting process by a broad range of countries with different cultural and legal backgrounds would have resulted in an evenly broad acceptance and application of the Convention. However, it appears that this has not quite been the case, as the geographical allocation of CISG-related case law shows. On 21 May 2004, a computerised search of the arguably most comprehensive and up-to-date CISG case database on the Internet operated by the Pace University Law School ("Pace database"), established the following results: out of a total of 1265 cases listed, the United States accounts for 56 decisions, followed at a distance by New Zealand (9), Australia (8) and Canada (8). ${ }^{15}$ In comparison, Germany has reported 350 decisions, followed by the Netherlands (102), Switzerland (101), Belgium (96), and Austria (90). ${ }^{16}$

This apparent scarcity of common law case law, reflected both by the total numbers of reported decisions and the disparity in numbers of cases reported in civil and common law countries, has led to the assumption that there are common law specific problems with the CISG. Indeed, these figures, while they should be treated with all due caution, raise the question of whether there are inherent features of either the CISG or the common law which so far have kept common law courts from contributing proportionately to the body of international CISG case law. This article reveals that most of the difficulties that emerge either do not pose lasting obstacles or were not common law specific in the first place.

13 Report of the Secretary-General "Incorporation of the Provisions of the Draft Convention on the Formation of Contracts for the International Sale of Goods into the Draft Convention on the International Sale of Goods" (A/CN.9/145) IX UNCITRAL Yearbook (1978) 121.

14 A good outline of the substantial rules of the Convention is provided by the New Zealand Law Commission Report No 23 The United Nations Convention on Contracts for the International Sale of Goods: New Zealand's Proposed Acceptance (Wellington, New Zealand, 1992).

15 Pace website search template $<$ http://www.cisg.law.pace.edu/cisg/search-cases.html $>$ (last accessed 21 May 2004).

16 These findings are confirmed by a search of the UNILEX database on the CISG, <http://www.unilex.info> (last accessed 21 May 2004), a project sponsored by UNIDROIT. On 21 May 2004, out of more than 541 listed CISG court cases, Germany, Austria, Switzerland, France, and The Netherlands account for 374 cases while only 41 cases are from common law countries like the United States (34), Australia and Canada (3 each) and New Zealand (1). 


\section{A The Common Law Approach to Interpreting Statutes and Treaties}

Several scholars have pointed out that common law jurisdictions traditionally use a narrow approach to interpreting statutes and treaties such as the CISG, which would not sit well with the international character of the Convention, especially in the light of Article 7(1) of the CISG. ${ }^{17}$ Common law judges, particularly in England, are said to be unwilling to have recourse to preparatory materials ('travaux preparatoires') or to refer to the genesis of a statute and its rules since the meaning of legislation must be deduced primarily (if not solely) from the words of the statute according to the so-called "literal rule". ${ }^{18}$ In civil law countries, by contrast, it is quite common to refer to the legislative history to resolve an interpretative problem. ${ }^{19}$ According to Audit, the reason for this narrow interpretation is the concept of written law as an exception to the common law. ${ }^{20}$

A narrow interpretative approach, which is inclined to ignore the legislative history and other externalities, would clearly be in conflict with Article 7(1) of the CISG. According to this provision, consideration must be given to the "international character" of the Convention and "to the need to promote uniformity in its application and the observance of good faith in international trade." In particular the reference to the international character of the Convention strongly suggests that courts should consult and refer to the Convention's legislative history and prior instruments (the ULIS and ULF) when interpreting provisions of the CISG. ${ }^{21}$

\section{The courts' approach to international conventions}

However, with respect to the interpretation of international conventions, it appears that common law courts have moved towards a broader, more civil-law-orientated approach to interpretation and that the rigidity of the literal rule has been eased not only in England but also in other common law countries. ${ }^{22}$

17 Kilian, above n 3, 217, 228-9, referring to Bernard Audit "The Vienna Sales Convention and the Lex Mercatoria" in Thomas E Carbonneay (ed) Lex Mercatoria and Arbitration (2 ed, Juris Publishing, New York, 1998) 173, 187; Robert G Lee "The UN Convention on Contracts for the International Sale of Goods: OK for the UK?" [1993] JBL 131, 147; Frank Diedrich "Maintaining Uniformity in International Law Via Automomous Interpretation of Software Contracts and the CISG" (1996) 8 Pace Int'l L Rev 303, 311.

18 Paul Volken "The Vienna Convention: Scope, Interpretation, and Gap-filling" in Petar Sarcevic and Paul Volken (eds) International Sale of Goods: Dubrovnik Lectures (Oceana, New York, London, Rome, 1986) 19, 39-40, referring to Guttenridge J; Franco Ferrari "Uniform Interpretation of The 1980 Uniform Sales Law" (1994-95) 24 Georgia J Int'l and Comp L 183, Chapter VIII.

19 Ferrari, above n 18, Chapter VIII.

20 Audit, above n 17, 187.

21 Ferrari, above n 18, Chapter VIII; Audit in Kilian, above n 3, 188.

22 Ferrari, above n 18, Chapter VIII; Sieg Eiselen "Adoption of the Vienna Convention for the International Sale of Goods (the CISG) in South Africa" (1996) 116 South African LJ, Part II, 323, 361-2. 
This new and promising approach was first observed in the 1977 case of James Buchanan \& Co Ltd v Babco Forwarding and Shipping (UK) Ltd, which concerned the interpretation of a provision of the Contract for the International Carriage of Goods by Sea (CMR) Convention of Geneva. ${ }^{23}$ In this case Lord Denning MR pointed out: ${ }^{24}$

This art 23, para 4, is an agreed clause in an international convention. As such it should be given the same interpretation in all the countries who were parties to the convention. It would be absurd that the courts of England should interpret it differently from the courts of France, or Holland, or Germany. ... We must, therefore, put on one side our traditional rules of interpretation. ... We ought, in interpreting this convention, to adopt the European method.

This decision was further reinforced by the decision in Fothergill $v$ Monarch Airlines, where the House of Lords made reference to the legislative history in order to interpret a provision of an international convention, in this case Article 26 of The Warsaw Convention of $1929 .{ }^{25}$ Lord Wilberforce stated: ${ }^{26}$

We are here concerned with what is in effect a private law convention likely to be litigated primarily in municipal courts. In the interest of uniformity of application we ought, in considering whether to use travaux preparatoires, to have regard to the general practice applied, or likely to be applied, in the courts of other contracting states.

These passages have induced similar decisions in other common law courts. In New Zealand, for instance, the Court of Appeal referred to both Fothergill and Buchanan v Babco in its decision in Integrity Cars (Wholesale) Ltd $v$ Chief Executive of NZ Customs Services. ${ }^{27}$ Keith J addressed the issue of interpreting legislation that is designed to give effect to an international agreement (here, the Agreement on Implementation of Article VII of the General Agreement on Tariffs and Trade 1994). As he explicitly pointed out, the agreement had to be given: ${ }^{28}$

23 James Buchanan \& Co Ltd v Babco Forwarding and Shipping (UK) Ltd [1977] 1 All ER 518 (CA) Lord Denning MR, affd [1977] 3 All ER 1048 (HL).

24 James Buchanan \& Co Ltd v Babco Forwarding and Shipping (UK) Ltd, above n 23, 522 (CA) Lord Denning MR.

25 Fothergill v Monarch Airlines Ltd [1980] 2 All ER 696, 706 (HL). The departure from the literal rule was justified on the ground that "the language ... has not been chosen by an English parliamentary draftsman. It is neither couched in the conventional English legislative idiom nor designed to be construed exclusively by English judges."

26 Fothergill, above n 25, 702 (HL) Lord Wilberforce.

27 Integrity Cars (Wholesale) Ltd v Chief Executive of NZ Customs Services (2 April 2001) CA 128/00.

28 Integrity Cars, above n 27, paras 19, 20. 
a uniform interpretation and application, so far as that can be achieved, ... because of its character as a world wide agreement.

That broad approach and the emphasis on uniformity also support reference to the developing international understanding of the meaning of the 1994 Agreement. That understanding may appear in the decisions of the courts of other parties to the Agreement.

As these decisions illustrate, common law courts are increasingly aware of their responsibility to strive towards the uniform interpretation of conventions and are willing and able to adopt different interpretative methods.

\section{Legislation concerning interpretation of statutes and treaties}

Further evidence of a change in common law statutory interpretation from a literal to more "purposive" approach may be derived from the enactment of domestic legislation concerning the interpretation of statutes. For example, in 1999 New Zealand enacted the Interpretation Act 1999. According to section 5(1) of this Act, the meaning of an enactment must be ascertained from its text and in the light of its purpose. ${ }^{29}$ This wording is said to reflect New Zealand's modern approach to statutory interpretation, which focuses on legislative purpose and scheme or context rather than on the letter of the law. ${ }^{30}$ Scheme or context refers to the internal context, the inner structure of the statute as well as its external context, which includes preceding law, social and economic circumstances at the time of its enactment and legislative history of an Act. ${ }^{31}$ Although section 5(1) of the Interpretation Act 1999 makes no reference to context, New Zealand courts have continuously made use of parliamentary history before and after $1999 .{ }^{32}$ In Australia, acceptance of the use of legislative history was accomplished when Commonwealth legislation was passed in 1984 expressly permitting courts to refer to a wide range of extrinsic materials. ${ }^{33}$

On an international level, the United Nations Convention on the Law of Treaties, signed at Vienna in 1969, provides further guidance on interpreting international treaties. ${ }^{34}$ Article 31(1) of this Convention sets out the general rule of interpretation which reads: "A treaty shall be interpreted

29 Emphasis added.

30 See John F Burrows and John Fogarty (presenters) "Statutory Interpretation" New Zealand Law Society Seminar, April 2001 (Butterworths, Wellington, 2001) 13-15, 28-9, citing Sir Ivor Richardson, according to whom purpose and scheme are the "twin pillars" of modern interpretation.

31 Burrows and Fogarty, above n 30, 14-20; John F Burrows Statute Law in New Zealand (3 ed, Butterworths, Wellington, 2003) 155 and following, 177 and following.

32 Burrows, above n 31, 181 and following.

33 Acts Interpretation Act 1901 (Cth), s 15AB, added in 1984.

34 The United Nations Convention on the Law of Treaties came into force on 27 January 1980. Common law participants include Australia, Canada, New Zealand, the United Kingdom and the United States. 
in good faith in accordance with the ordinary meaning to be given to the terms of the treaty in their context and in the light of its object and purpose." As a supplementary means of interpretation, Article 32 allows recourse both to the preparatory work of the treaty and the circumstances of its conclusion to determine the meaning when its interpretation is ambiguous. This has been acknowledged as the proper approach when interpreting incorporated treaties such as the CISG..$^{35}$

\section{Conclusion}

The traditional common law rule of interpretation (the literal approach) does not appear to pose a threat to the application of the CISG in common law countries. The modern common law approach to statutory interpretation rather focuses on the purpose and the context of legislation. As case law bears witness, courts have become familiar with the practice of referring to extrinsic materials such as the legislative history. The purposive approach is also embodied in the United Nations Convention on the Law of Treaties of 1969, which has been signed by all major common law jurisdictions and has been acknowledged as the proper way to interpret incorporated conventions such as the CISG. The contention of a specific common law issue pertaining to statutory interpretation, therefore, seems to be clearly outdated.

\section{B The Lack of Common Law Concepts}

According to Kilian, another obstacle to the acceptance of the CISG in common law countries is the fact that it lacks some of the well-established common law concepts such as consideration, Statute of Frauds and the parol evidence rule. ${ }^{36}$ The absence of these concepts in the Convention's text has presented common law courts with some challenges as to how to deal with parties' arguments based on these concepts.

\section{Homesick courts - The longing for a parol evidence rule}

The parol evidence rule basically states that any parol (oral or any other extrinsic) evidence cannot be permitted to alter, contradict or explain the terms of a written contract. ${ }^{37}$ In construing an unambiguous, and integrated contract, a court therefore may not consider evidence of prior or contemporary agreements among the parties, or evidence of their intentions regarding the contract. In contrast, Article 8(3) of the CISG, in connection with Article 8(1), provides that when it comes to interpreting a party's statements and conduct "due consideration is to be given to all relevant

35 For New Zealand, see Morag McDowell and Duncan Webb The New Zealand Legal System: Structure, Processes and Legal Theory (3 ed, LexisNexis Butterworths, Wellington, 2002) 346, para 8.8.5.

36 Kilian, above n 3, 230; John E Murray "An Essay on the Formation of Contracts and Related Matters under the United Nations Convention on Contracts for the International Sale of Goods" (1988) $8 \mathrm{~J}$ of L and Commerce 11, 12: "We are struck by a new world where there is no consideration, no statute of frauds, and no parol evidence rule, among other differences."

37 G H Treitel The Law of Contract (9 ed, Sweet \& Maxwell, London, 1995) 176-177. 
circumstances of the case including the negotiations, any practices which the parties have established between themselves, usages and any subsequent conduct of the parties." It has always been a common perception among scholars that Article 8(3) of the CISG overrides any domestic parol evidence rule. ${ }^{38}$ However, it has become obvious in two United States cases that the CISG's relation to the parol evidence rule poses a problem for common law courts.

In Beijing Metals \& Minerals v American Business Centre Inc of 1992, a Texas corporation defended itself against a contract claim of a Chinese corporation by relying on evidence of contemporarily negotiated oral terms that the parties had not included in their written agreement. ${ }^{39}$ While the plaintiff relied on Texas law in its complaint, the defendant asserted that the CISG governed the dispute. Without resolving the choice of law question, the Court of Appeals for the Fifth Circuit stated that the parol evidence rule would apply regardless of whether Texas law or the CISG governed the dispute and, therefore, excluded the testimony about oral terms under the state's parol evidence rule. ${ }^{40}$

Six years later, a Federal District Court simply ignored Article 8(3) of the CISG in MCCMarble Ceramic Center Inc v Ceramica Nuova D'Agostino SpA, although the parties to this case agreed that the CISG governed their dispute. ${ }^{41}$ A United States buyer had orally agreed with the Italian seller that the standard terms of a contract should not apply and then signed the standard contract. After a dispute arose, the judge did not allow evidence in the form of affidavits admitted to alter the terms of the written standard contract, thereby applying the parol evidence rule in derogation of Article 8(3) of the CISG.

Both judgments reveal a significant degree of ignorance and reluctance to deal with the CISG more closely. In their haste to reach the safe harbour of domestic law (in this case the well established and familiar parol evidence rule) the Courts did not even make an attempt to interpret the CISG in a manner that would arrive at a result consistent with the parol evidence rule. It therefore might be said that such 'homesick' courts pose a threat to the unification goal of the CISG.

38 John O Honnold Uniform Law For International Sales (3 ed, Kluwer Law International, The Hague, 1999) 121, para 110; Albert H Kritzer Guide to Practical Applications of the United Nations Convention on Contracts for the International Sale of Goods (Kluwer Law and Taxation Publishers, Deventer, The Netherlands, 1989) 125; Jan H Dalhuisen Dalhuisen on International Commercial, Financial and Trade Law (Hart Publishing, Portland, United States, 2000) 262-3.

39 Beijing Metals \& Minerals v American Business Centre Inc (1993) 993 F 2d 1178 (5th Cir).

40 Beijing Metals, above n 39, 1182-83, n 9.

41 MCC-Marble Ceramic Centre Inc v Ceramica Nuova D'Agostino SpA (1998) 114 F 3d 1384 (11 ${ }^{\text {th }}$ Cir) Kehoe J. 


\section{MCC-Marble and the displacement verdict}

It appears though, that common law courts, especially in the United States, have meanwhile resolved the issue of parol evidence under the CISG. Today, there is a persuasive and growing body of case law, according to which Article 8(3) of the Convention clearly precludes the application of the parol evidence rule.

The United States Court of Appeals settled the matter once and for all when it reversed and remanded the District Court's judgment in MCC-Marble, holding that Article 8(3) of the CISG displaces the parol evidence rule. ${ }^{42}$ After ascertaining that the CISG did not contain an express statement on the role of parol evidence, the Court, as a first step, carefully read and evaluated Article 8 of the CISG, and also gave regard to other articles of the Convention, such as Article 11. Secondly, the Court discussed the scarce United States case law touching upon the parol evidence rule. It explicitly rejected the opinion in Beijing Metals as being "not particularly persuasive on this point". 43 As a third step of interpretation, the Court then did not hesitate to refer extensively to and rely on scholarly authority on both sides of the debate of the parol evidence rule under the CISG. ${ }^{44}$ It rebuffed the arguments of David Moore, the only commentator reconciling the parol evidence rule with the CISG, by referring to the supranational character of the Convention and its general avoidance of domestic legal principles. ${ }^{45}$

With its sound methodology and clear statement, the Court of Appeals' decision in MCCMarble has become a precedent not only in respect of the parol evidence rule but also for United States case law on the CISG in general. ${ }^{46}$ The 'displacement verdict' of MCC-Marble has been confirmed, for example, by the District's Court decisions in Mitchell Aircraft Spares Inc v European Aircraft Service $A B$ in $1998^{47}$ and Shuttle Packaging Systems LLC v Jacob Tsonakis in $2001{ }^{48}$ The

42 MCC-Marble, above n 41.

43 MCC-Marble, above n 41, 1390.

44 MCC-Marble, above n 41, 1390 n 17, citing, amongst others, John O Honnold, Herbert Bernstein, Joseph Lookofsky, Harry M Flechtner, John E Murray, and Peter Winship.

45 MCC-Marble, above n 41, 1390-1, referring to David H Moore (Note) "The Parol Evidence Rule and the United Nations Convention on Contracts for the International Sale of Goods: Justifying Beijing Metals \& Minerals Import/Export Corp v American Business Center, Inc" (1995) Brigham Young U L Rev1347.

46 Kilian, above n 3, 233; the methodology, in particular, has been praised by Harry M Flechtner "The UN Sales Convention (CISG) and MCC-Marble Ceramic Centre Inc v Ceramica Nuova D'Agostino, SpA: The Eleventh Circuit Weighs in on Interpretation, Subjective Intent, Procedural Limits to the Convention's Scope, and the Parol Evidence Rule" (1999) 18 J L and Commerce 259, 269.

47 Mitchell Aircraft Spares Inc v European Aircraft Service AB (1998) 23 F Supp 2d 915, 920-21 (ND Ill ED).

48 Shuttle Packaging Systems, LLC v Jacob Tsonakis, INA SA and INA Plastics Corporation (17 December 2001) 1:01-CV-691 (WD Mich SD) <http://www.cisg.law.pace.edu/cisg/text/casecit. html\#us> (last accessed 21 May 2004). 
Courts in two other United States cases essentially reached the same conclusion as in MCC-Marble, though they did not refer to it. As early as 1992 the District Court in Filanto SpA $v$ Chilewich International Corp, though in dicta, stated that "[i]t should also be noted that ... the Convention essentially rejects both the Statute of Frauds and the parol evidence rule."49 Finally, in Calzaturificio Claudia v Olivieri Footwear the Court held that "contracts governed by the CISG are freed from the limits of the parol evidence rule and there is a wider spectrum of admissible evidence to consider in construing the terms of the parties' agreement". 50

\section{Consideration under the CISG}

The findings for the relation between the Convention and the common law doctrine of "consideration" are not quite as comforting. The Convention's approach towards consideration is indicated by Article 29(1) of the CISG, whereby "[a] contract may be modified or terminated by the mere agreement of the parties." According to the Secretariat Commentary, the closest counterpart to an official commentary, this provision was intended to "eliminate" and "overrule" the common law consideration requirement. ${ }^{51}$ This underlying intent was acknowledged in Shuttle Packaging Systems LLC $v$ Jacob Tsonakis. In this case the Court rejected the defendants' argument that a complementary agreement between the parties was ineffective due to lack of consideration. Referring to Article 29 of the CISG, it held that "under the Convention, a contract for the sale of goods may be modified without consideration for the modification."52

However, in Geneva Pharmaceuticals Technology Corp v Barr Laboratories Inc the District Court of New York took another approach to consideration under the CISG. ${ }^{53}$ A Canadian manufacturer of chemicals had supplied the plaintiff United States company with samples of a chemical ingredient and agreed to support the Company's application for approval by the Food and Drug Administration (FDA) as the supplier of the ingredient for the manufacture of the drug. After the approval the plaintiff submitted a purchase order, which the Canadian firm rejected due to obligations under another contract. The Canadian defendant, amongst other things, claimed that consideration was lacking as a question of validity. Without closer examination of the Convention's attitude towards consideration, the Court found that "[u]nder the CISG, the validity of an alleged contract is decided under domestic law, CISG Art 4(a)" and regarded consideration as a validity

49 Filanto SpA v Chilewich International Corp (1992) 789 F Supp 1229, 1238 n 7 (SD NY).

50 Calzaturificio Claudia v Olivieri Footwear (6 April 1998) 96 Civ 8052 (HB) (THK) (SD NY) <http://www.cisg.law.pace.edu/cisg/text/casecit.html\#us> (last accessed 21 May 2004).

51 Secretariat Commentary on Article 27 of the 1978 draft (draft counterpart of Article 29) paras 2.3 <http://www.cisg.law.pace.edu/cisg/text/secomm/secomm-29.html> (last accessed 21 May 2004).

52 Shuttle Packaging Systems, LLC v Jacob Tsonakis, INA SA and INA Plastics Corporation (17 December 2001) 1:01-CV-691 (WD Mich SD).

53 Geneva Pharmaceuticals Technology Corp v Barr Laboratories Inc (2002) 201 F Supp 2d 236 (SD NY). 
issue to be governed by internal domestic law. The Court then discussed and approved consideration under New Jersey law.

This case illustrates what has been denounced as the "black hole" function of Article 4 of the CISG. ${ }^{54}$ Article 4(a) of the CISG provides that unless otherwise expressly provided, the Convention is not concerned with the validity of the contract. As foreseen by several scholars the very reason for excluding issues of validity from the CISG - the differing and strongly felt national traditions have seduced judges into too readily identifying issues of validity in a dispute in order to be able to return to national law solutions, turning Article 4(a) of the CISG into a "black hole" for originally non-validity questions. ${ }^{55}$ The District Court of New York managed to request and find consideration in a CISG case although the Convention rejects the requirement of consideration in Article 29 and abandons it in its formation rules.

The vice of introducing national law and legal doctrine through the back door, however, is not unique to common law courts, as the following case illustrates. The German District Court (Amtsgericht) of Nordhorn was concerned with a dispute between an Italian seller and a German buyer arising from a contract for the sale of shoes. ${ }^{56} \mathrm{~A}$ clause in the seller's general conditions of contract provided that the buyer could avoid the contract only following a notice demand to the seller to comply with the contract and then only after 15 working days from the date that the seller received the notice to comply. After an allegedly belated delivery the buyer declared the contracts avoided and the seller sued the buyer for full payment. Referring to the assessment of standard terms and conditions in general, the Court held that the validity of the seller's conditions was beyond the scope of the Convention, according to Article 4(a) of the CISG, and had to be determined according to the law governing the contract (in this case Italian law). The Court did not bother to check first whether the question at hand was governed by the provisions and general principles of the Convention. If it had done so, it would have found that the contractual requirements for avoidance were not that different from the provisions of Article 47 of the CISG

54 Peter Winship "Commentary on Professor Kastely's Rhetorical Analysis" (1987-88) 8 Northwestern J Int'l L and Business 623, 636.

55 Winship, above n 54, 637; John O Honnold Uniform Law for International Sales (2 ed, Kluwer Law and Taxation Publishers, Deventer, The Netherlands, 1991) 283, paras 204.2-204.4.

56 Amtsgericht Nordhorn (14 June 1994) 3 C 75/94 <http://www.unilex.info> (last accessed 21 May 2004). 
and its general underlying principles. ${ }^{57}$ According to Koneru, "[t]he inquiry should not have been whether such clause was valid, but rather whether the time fixed was a reasonable time."58

Koneru's criticism points at a way out of the "black hole" dilemma. Based on an approach developed by Honnold, several commentators suggest that, as a general rule, the Convention displaces domestic law governing validity issues if its provisions and general principles address the issue and provide a solution on the same operative facts. ${ }^{59}$ The merits of this "displacement theory"60 are that it does not have to rely on the labels attached to validity by domestic laws. ${ }^{61}$ Instead, "it emphasises that, in drafting the Convention, it was sought not to use technical terms but to provide 'substance rather than label(s) of law'".62 The Secretariat Commentary on Article 4 of the CISG confirms this notion. It states:63

Although there are no provisions in this Convention which expressly govern the validity of the contract or of any usage, some provisions may provide a rule which would contradict the rules on validity of contracts in a national legal system. In case of conflict the rule in this Convention would apply.

This "displacement reading" provides an elegant solution to the validity issue because it satisfies two needs at the same time. It provides an interpretative method for Article 4(1), which is suitable for legal practice because the validity issue can be classified according to domestic law. ${ }^{64}$ At the

57 Article 47(2) of the CISG reads: "Unless the buyer has received notice from the seller that he will not perform within the period so fixed, the buyer may not, during that period, resort to any remedy for breach of contract. However, the buyer is not deprived thereby of any right he may have to claim damages for delay in performance."

58 Phanesh Koneru "The International Interpretation of the UN Convention on Contracts for the International Sale of Goods: An Approach Based on General Principles" (1997) 6 Minnesota J Global Trade 105 n 189.

59 John O Honnold Uniform Law for International Sales (2 ed, Kluwer Law and Taxation Publishers, Deventer, The Netherlands, 1991) 117, para 69, 311-2 paras 234, 240; Ulrich Magnus J von Staudingers Kommentar um Bürgerlichen Gesetzbuch mit Einführungsgesetz und Nebengesetzen: Wiener UN-Kaufrecht (CISG) (Sellier - de Gruyter, Berlin, 1994) 77 and following. Article 4 paras 3-5, 27; Bell, above n 1, 253-4.

60 The label was formulated by Patrick C Leyens "CISG and Mistake: Uniform Law vs Domestic Law: Mistake as an Interpretative Challenge under the "Validity Loophole" of Art. 4(a) of the Vienna Convention 1980" (30 March 2003) <http://www.cisg.law.pace.edu/cisg/biblio/levens.html\#131> (last accessed 21 May 2004).

61 Honnold, above n 59, 318, para 240.

62 Leyens, above n 60, Ch III C 4, before n 133, citing Bianca and Bonell (eds) Commentary on the International Sales Law - The 1980 Vienna Sales Convention (Giuffrè, Milan, 1987).

63 Secretariat Commentary Guide to CISG Art 4 para 2 <http://www.cisg.law.pace.edu.cisg/text/secomm> (last accessed 21 May 2004).

64 Leyens, above n 60, Ch III C 4. 
same time it is consistent with the unification purposes of the Convention without ignoring the public policy background of many domestic validity provisions.

Applying this approach, Honnold has evaluated the different provisions of the CISG relevant to the issue of consideration and found that "on each occasion when this question came to the fore (Articles 16, 29) the Convention rejected 'consideration' as a barrier to enforcing the agreement." He, therefore, concludes that this permanent rejection amounts to one of the "general principles" pursuant to Article 7(2) of the CISG. I agree with this view, particularly in the light of Article 7(1) of the CISG, which requires the Convention to be interpreted with regard "to its international character and the need to promote uniformity in its application." 65

\section{Conclusion}

In summary, it can be said that the lack of common law concepts no longer presents an insurmountable obstacle to the courts. The issue of the parol evidence rule has been settled by a clear and concise court decision that now serves as valuable precedent for CISG case law. As to the doctrine of consideration, courts should use the guidance provided by Professor Honnold and acknowledge a general non-requirement of consideration in CISG cases. The example of the parol evidence rule in particular gives reason to believe that common law courts are willing and able to engage with the Convention without bias as a new agreement.

\section{The Reliance on CISG Precedents}

Kilian claims that "the unwillingness of common law judges to apply the CISG is due to the lack of precedents among common law jurisdictions applying CISG, simply because common law judges want to get their precedents in first". ${ }^{66}$ In fact, United States judges, for instance, have repeatedly lamented that "there is virtually no case law under the Convention"67 or "little to no case law on the CISG in general" 68 before entering the discussion and, more or less, applying and interpreting the substantive rules of the Convention. Two aspects could explain this dependence on precedent: the alleged reluctance of common law courts to refer to scholarly opinion and the fact that the United Kingdom (UK) does not contribute to CISG case law because it has not signed the Convention. However, as the following will show, neither aspect poses a significant threat to the further development of common law case law. Moreover, the existing body of common law case law dealing with the CISG is possibly not as bleak as the relevant databases suggest.

65 Honnold, above n 59, 284, para 204.4

66 Kilian, above n 3, 233.

67 Delchi Carrier SpA v Rotororex Corp (1995) 71 F 3d 1024, 1027-28 (2nd Cir). The words cited above occur in the second sentence of the case discussion.

68 Helen Kaminski v Marketing Australia Products (1997) No 96B46519 (SD NY) <http://www.cisg. law.pace.edu/cisg/wais/db/cases2/970721u1.html> (last accessed 21 May 2004). 


\section{Courts' reluctant reference to scholars}

Kilian calls the decision in MCC-Marble "remarkable" also because the Court of Appeal referred to and relied on scholarly studies for support of its opinion. ${ }^{69}$ She notes that this is "a civil law rather than a common law practice."70 Indeed, judges in England and the United States have been traditionally reluctant to have recourse to scholarly writing. ${ }^{71}$ This reluctance might be another common law specific problem with the application of the CISG. Considering the tendency of common law courts to rely on precedents to a much greater degree than civil law courts and the scarcity of precedent case law given, a general reluctance to take into account scholarly authority adds to the difficulty of interpreting the Convention and achieving consistent judgments in CISG cases for common law courts.

However, as Ferrari and Honnold have observed, recourse to scholarly writing has become more and more common in common law countries, in particular in interpreting international conventions such as the CISG. ${ }^{72}$ In the United States case Usinor Industeel v Leeco Steel Products, for example, Judge Lindberg, after noting that "federal case law interpreting and applying the CISG is scant", did not hesitate to refer to and discuss the scholarly writings of Honnold and other academics to determine whether Article 4(b) of the CISG was applicable in the case at hand. ${ }^{73}$ In New Zealand, the Honourable Robert Fisher has stressed the advantage of reference to academic authorities: "Legal academics are more likely than Judges and practitioners to study, work, and read internationally and across disciplines. They specialise in ways that can sometimes be difficult for general practitioners and Judges to emulate. ..."74 And in fact, as an empirical study by Smyth has revealed, the New Zealand Court of Appeal regularly cites academic authorities in its decisions, though not as frequently as Australian or United States courts. ${ }^{75}$

69 Kilian, above n 3, 233; see MCC-Marble Ceramic Center Inc v Ceramica Nuova D'Agostino SpA (1998) 144 F 3d 1384, 1390-91, citing numerous prominent legal scholars, including John Honnold, Harry M Flechtner, John E Murray and Peter Winship.

70 Kilian, above n 3, 233; see also Michael P Van Alstine "Dynamic Treaty Interpretation" (1998) 146 L Penn L Rev 687, 788.

71 Franco Ferrari "Uniform Interpretation of The 1980 Uniform Sales Law" (1994-95) 24 Georgia J Int'l and Comp L 183, ch VIII.

72 Ferrari, above n 71, ch VIII; John O Honnold "The Sales Convention in Action - Uniform International Words: Uniform Application?" (1988) 8 J L and Commerce 207, 208.

73 Usinor Industeel v Leeco Steel Products (2002) 209 F Supp 2d 880 (ND Ill ED).

74 Hon Robert Fisher "New Zealand Legal Method: Influences and Consequences" in Rick Bigwood (ed) Legal Method in New Zealand: Essays and Commentaries (Butterworths, Wellington, 2001) 25, 42.

75 Russell Smyth "Judicial Robes or Academic Gowns? - Citation of Secondary Authority and Legal Method in the New Zealand Court of Appeal" in Bigwood, above n 74, 101; 117 and following. 


\section{UK's non-acceptance - A missing role model or a stumbling block?}

Another probable reason for the paucity of CISG case law from common law countries, and a potentially significant factor for its further development, is the fact that the United Kingdom, the "cradle of common law", ${ }^{76}$ has yet not accepted the Convention. ${ }^{77}$ Although the United Kingdom was represented on the UNCITRAL working group in $1969^{78}$ and at the conference in Vienna, it did not sign the Convention in 1980 or in the years following. The primary reasons for the United Kingdom's abstention seem to be rather nationalistic in nature. According to the Law Society of England and Wales, one concern was that "the Convention would result in a diminished role for English law within the international trade arena."79 Goode has also spotted "a naïve belief" in the superiority of the United Kingdom's Sale of Goods Act, which has remained largely unchanged for over one hundred years but which, according to Dalhuisen, has never set a pattern in international sales. ${ }^{80}$ It should be noted that these objections to the Convention appear to be based on cloudy fear and an inkling of chauvinism rather than on precise criticism of the rules and operation of the Convention.

However, the United Kingdom's rejection of the CISG has presumably deprived other common law countries of valuable case material that could serve as precedent or at least provide guidance.

Another more indirect, but nonetheless detrimental effect of the United Kingdom's stance towards the CISG is illustrated by the New Zealand decision in the 2000 case of Yoshimoto $v$ Canterbury Golf International Ltd. ${ }^{81}$ In this case, the Court of Appeal was concerned with the interpretation of a clause in a share purchase agreement between a Japanese businessman and a New

76 Kilian, above n 3, 233.

77 Though there has been some support for accession, see Department of Trade and Industry United Nations Convention on Contracts for the International Sale of Goods (Vienna Sales Convention): A Consultation Document (DTI, London, United Kingdom, June 1998) paras 22-23; Anette Gärtner "Britain and the CISG: The Case for Ratification - A Comparative Analysis with Special Reference to German Law" in Pace Review of the Convention on Contracts for the International Sale of Goods (CISG) (Kluwer Law International, New York, 2000-2001) 59.

78 See Report of the Working Group on the International Sale of Goods of its First Session (1970) I UNCITRAL Yearbook 176, 177.

79 Law Reform Committee of the Council 1980 Convention on Contracts for the International Sale of Goods (Law Society of England and Wales, 1981), other objections to the Convention were (1) that it would not produce uniformity because of differing national interpretation, (2) that commercial traders could easily avoid the Convention, and (3) that the Convention would more commonly apply by default due to the 'optout' provision; see also Robert G Lee "The UN Convention on Contracts for the International Sale of Goods: OK for the UK?" (1993) JBL 131, 132.

80 Roy M Goode Commercial Law (2 ed, Penguin Books, London, 1995) 926; Jan H Dalhuisen Dalhuisen on International Commercial, Financial and Trade Law (Hart Publishing, Portland, United States, 2000) 250.

81 Yoshimoto v Canterbury Golf International Ltd [2001] 1 NZLR 523 (CA). 
Zealand company. Their Honours unanimously held that the true meaning of the clause was sufficiently indicated by the contract, the commercial purpose, and the contractual matrix. However, Thomas $\mathrm{J}$ also confronted the question of whether regard may be had to extrinsic evidence, which he thought was both admissible and reliable in this case. He noted, however, that there was a right of further appeal to the Privy Council in London and that previous cases had shown "the reluctance of the English Courts to look at extrinsic evidence as an aid to interpretation."82 But His Honour also pointed out that it was in the Court's discretion to depart from the law as applied in England on the basis that New Zealand had implemented the CISG in $1995 .{ }^{83}$ After citing Article 8 of the CISG, on the interpretation of international sale contracts, Thomas $\mathrm{J}$ referred to his judgment in Attorney General \& NZ Rail Corporation v Dreux Holdings Ltd by saying that the approach of the courts in New Zealand to the interpretation of contracts should be consistent with the best international practice. ${ }^{84}$

However, Thomas J doubted the Privy Council would permit New Zealand courts to depart from the law as applied in England and bring the law in New Zealand into line with international conventions. He pointed out that England had failed to adopt the CISG and had shown little readiness to allow New Zealand courts any latitude in the interpretation of contracts. He stated: 85

Being realistic, the law of contract in this country, other than as specifically reshaped by statute, is likely to remain the law of England. Indeed, in 1985 the Privy Council made it clear that, apart from cases involving considerations peculiar to New Zealand or questions of local policy, the Courts of New

Zealand must adhere to the law which is of general application as the common law of England.

The United Kingdom's attitude towards the CISG coupled with the difficulty in departing from established English case law, therefore, has hampered common law countries in harmonising their domestic adjudication with international practice. However, it should be noted that in Yoshimoto the CISG was not applicable, presumably because the contract in question was for the sale of shares. ${ }^{86}$ Most likely, this hampering effect would not take place in a case where the CISG applies.

Moreover, there has been a clear movement towards the independence of the New Zealand courts in the last few years. In Invercargill City Council v Hamlin the Privy Council explicitly permitted the New Zealand Court of Appeal to depart from English case law on the grounds "that

82 Yoshimoto, above n 81, 546 Thomas J.

83 Yoshimoto, above n 81, 547 Thomas J.

84 Attorney-General and NZ Rail Corporation v Dreux Holdings Ltd (1996) 7 TCLR 617, 627; 642 (CA).

85 Yoshimoto, above n 81, 547, para 90.

86 Neither their Honours nor any of the parties addressed this matter. 
conditions in New Zealand are different". ${ }^{87}$ Moreover, the Court of Appeal has repeatedly stated that it does not consider itself bound by the decisions of the House of Lords, the highest Court in the United Kingdom. ${ }^{88}$ The degree of independence indicated by these decisions, remedies to some degree the stumbling block posed by the United Kingdom's non-acceptance.

3 The distorting lens - case databases and reality

The lament of judges and scholars about the lack of CISG-related common law decisions is often backed up by the poor results from searches of electronic case databases. McNamara refers to a computerised search of United States legal databases conducted in October 2000 to demonstrate that in Colorado the CISG is still an unproven commodity. ${ }^{89}$ In her assessment of the CISG's problems in common law jurisdictions Kilian bases her assumptions on the numbers of CISGrelated decisions for individual common law member states drawn from the Pace website. ${ }^{90}$ Even the author of this article has resorted to database material to illustrate the gap between civil law and common law case numbers.

While it should not be denied that (electronic) case databases reflect the reality of case law to some extent, it should be borne in mind that in most cases there is no automated updating process that ensures the completeness of these databases' material. In fact, databases devoted to collecting CISG related material are often dependent on voluntary submissions by different kinds of contributors, and are maintained by universities and institutes as a free public service. ${ }^{91}$ This data collection mechanism bears the risk of incompleteness. Therefore, it is possible that the data provided by these databases does not appropriately reflect reality and, consequently, can have a rather distorting effect.

New Zealand serves as an example to prove this contention. As of 30 September 2003, the official UNCITRAL CISG case law collection CLOUT listed not one single New Zealand case or

87 Invercargill City Council v Hamlin [1996] 1 NZLR 513, 519 (PC) Lord Lloyd of Berwick. Admittedly, Invercargill was a tort case and, therefore, could be considered as involving "questions of local (public) policy".

88 For example Busby v Thorn EMI Video Programme Ltd [1984] 1 NZLR 461 (CA); Pacific Coilcoaters Ltd v Interpress Associates Ltd [1998] 2 NZLR 19, 32 (CA) Thomas J.

89 Tom McNamara "United Nations Convention on Contracts for the International Sale of Goods" (paper presented to the National Association of Purchasing Management, Denver Affiliate, 16 November 2000) 4, 8 <http://www.dgslaw.com/articles/334336.html> (last accessed 21 May 2004).

90 Kilian, above n 3, 218.

91 See CISG Case Law Database, Pace website <http://www.cisg.law> (last accessed 21 May 2004); UNLEX CISG database, International Institute for the Unification of Private Law (UNIDROIT) <http://www.unilex.info> (last accessed 21 May 2004); only the official UNCITRAL CISG case law collection CLOUT relies on a network of national correspondents designated by member states to monitor and collect relevant court decisions and arbitral awards. 
arbitral award relating to the CISG. ${ }^{92}$ A search of the Pace website and the UNILEX database produced only one case each for New Zealand. ${ }^{93}$ In both decisions the CISG did not govern the contractual relation but was merely referred to by judges in dicta to illustrate specific insufficiencies of domestic New Zealand law. ${ }^{94}$ However, the author's own research revealed that there were several other cases of at least comparable significance which had been decided by New Zealand courts but had so far not been listed in any CISG related case database. ${ }^{95}$ These cases are set out below.

Attorney-General \& NZ Rail Corporation v Dreux Holdings Ltd concerned the interpretation of a clause in a purchase agreement between two New Zealand parties. ${ }^{96}$ The Court of Appeal had to deal with the question of whether it is permissible in interpreting a contract to take into account the conduct of parties subsequent to entering the contract. Although their Honours were able to decide the particular case without having to resolve this issue, they pointed out that having regard to subsequent conduct is an established international practice, as recognised by the Vienna Sales Convention. Blanchard $\mathrm{J}$ for the majority stated that "[i]t should not go unnoticed that the United Nations Convention on Contracts for the International Sale of Goods, ... is now, by virtue of the Sale of Goods (United Nations Convention) Act 1994, part of New Zealand law."97 After quoting Article 8(3) of the CISG their Honours continued to say that "there is something to be said for the idea that New Zealand domestic contract law should be generally consistent with the best international practice." 98 However, they noted that the question had been left open in Australia, another member state to the CISG, and that New Zealand courts should consider consistency with Australian domestic law in determining such questions. In a minority judgment, Thomas $\mathrm{J}$ even considered it to be "clearly desirable that interpretation of contracts by courts in New Zealand coincides with international practice." 99

92 CLOUT < http://www.uncitral.org/en-index.htm> (last accessed 21 May 2004).

93 CISG Database (Country Case Schedule), Pace website <http://www.cisg.law.pace.edu/cisg/text/ casecit.html\#newzealand> (last accessed 30 September 2003): Crumb v Wala (1993) 6 TCLR 40 (HC); UNILEX database <http://www.unilex.info> (last accessed 30 September 2003): Yoshimoto v Canterbury Golf International Ltd [2001] 1 NZLR 523 (CA).

94 Crumb v Wala (1993) 6 TCLR 40, 47 (HC) Hammond J: New Zealand had not yet become a signatory to the CISG in 1993 and both seller and buyer had their places of business in New Zealand.

95 With respect to the Pace website, this has changed. As of 21 May 2004, the Country Case Schedule of the Pace website contains nine cases.

96 Dreux Holdings Ltd, above n 84.

97 Dreux Holdings Ltd, above n 84, 627 Blanchard J for the majority.

98 Dreux Holdings Ltd, above n 84, 627 Blanchard J for the majority.

99 Dreux Holdings Ltd, above n 84, 642 Thomas J. 
In two other cases, BP Oil (NZ) Ltd v Rhumvale Resources Ltd ${ }^{100}$ and Integrity Cars, ${ }^{101}$ the Courts briefly considered the application of the CISG but rejected it for obvious reasons.

Thompson $v$ Cameron concerned the issue of whether a New Zealand court can have regard to pre-contractual negotiations and post-contract conduct when interpreting an ambiguous contract. ${ }^{102}$ Dealing with this question, Chambers J referred to the Court of Appeal's decision in Dreux Holdings and its recourse to the interpretation rules of Article 8(3) of the CISG. ${ }^{103}$ He noted that the Court of Appeal had not expressed a firm view on the issue and had given authorities both for and against the admissibility of evidence of subsequent conduct. However, he concluded that there was at least a tentative view in favour of admissibility in Dreux Holdings. ${ }^{104}$ Therefore, and for practical reasons, Chambers $\mathrm{J}$ permitted one party to give evidence of both of pre-contractual negotiations and subsequent conduct, though he was able to solve the dispute without having to refer to that evidence.

Finally, an interim judgment in KA (Newmarket) Ltd v Hart dealt with the relation between the CISG and the domestic sales law of New Zealand in terms of applicability. ${ }^{105}$ The Australian plaintiffs based one of their claims on the breach of a term implied in the above-mentioned agreement by New Zealand's Sale of Goods Act 1908. Heath J decided that the pleading failed in this regard because the Sale of Goods Act 1908 did not apply to a transaction between parties in Australia and New Zealand but only to domestic New Zealand transactions. He then referred to the CISG as the applicable law for "contracts for the sale of goods between Australia and New Zealand."106

These cases show that the New Zealand case law dealing with the CISG is not limited to one or two cases. It is beyond the scope of this article to ascertain whether this is also true for other common law jurisdictions such as Canada or Singapore. However, a similar or less distorting ratio between database cases and existing cases is not totally improbable. The New Zealand cases also show that judges and courts are willing and able to refer to and invoke the provisions of the CISG even in cases where the Convention is not directly applicable. Therefore, McNamara's conclusion

100 BP Oil (NZ) Limited v Rhumvale Resources Limited (1997) 8 TCLR 116 (CA).

101 Integrity Cars (Wholesale) Ltd, above n 27.

102 Thompson v Cameron (27 March 2002) HC Ak AP 117/SW99, B 1257/IM01, Chambers J.

103 Thompson $v$ Cameron, above n 102, para 20.

104 Thompson v Cameron, above n 102, para 20 (emphasis added).

105 KA (Newmarket) Ltd \& Ors v Hart \& Anor (10 May 2002) HC Ak CP 467 SD01, Heath J.

106 KA (Newmarket), above n 105, para 68. 
that the low number of CISG cases produced by database searches somehow prove that courts are unfamiliar with the CISG is at least questionable. ${ }^{107}$

\section{Unfamiliar courts or ignorant parties?}

The idea that unwilling or ignorant judges can be blamed for the scarcity of CISG case law from common law countries might be inaccurate from another point of view. As reported decisions indicate, it often appears to be the parties and their legal advisors who behave ignorantly or are unfamiliar with the CISG. Thus, the scarcity of CISG-related case law might be ultimately a result of the adversarial court system of common law countries. In contrast to the inquisitorial system employed in most civil law countries, it does not require the adjudicator or court to actively participate in the fact-finding process. Instead, the Court's judgment largely relies on the arguments of the parties and their lawyers for and against a case. ${ }^{108}$

In the Australian decision Roder Zelt und Hallenkonstruktionen GmbH v Rosedown Park Pty $L t d$ the Federal Court of Australia explicitly criticised the parties' ignorance of the CISG. ${ }^{109}$ In this case, Roder, a German company, had sold tent hall structures to the Australian firm Rosedown. Under the contract, Rosedown had to pay for the goods by instalments but fell behind in its payments. It was subsequently placed under administration in accordance with the Australian corporations law. Roder sued Rosedown and the administrator, claiming, amongst other things, that it had retained ownership of the goods by virtue of a retention of title clause in the sales contract. The trial Judge, von Doussa J, held that the contract was governed by the CISG because it was for the sale of goods and both parties had their places of business in Contracting States to the CISG. ${ }^{110}$ With regard to the remedies available to Roder, he pointed out that the parties had referred to the contract of sale being "repudiated" and to the acceptance of "the said repudiation". These "common law concepts", he did not hesitate to emphasise, "are replaced by the provisions of the Convention."111 In a side note, he explicitly criticised that the parties' pleadings were wrongly "expressed in the language and concepts of the common law, not in those of the convention." ${ }^{\text {112 }}$

The Supreme Court of South Australia went even further in its criticism of the parties. In the 2001 case of Perry Engineering $v$ Bernold an Australian plaintiff tried to sue a Swiss firm by relying on the South Australian Sale of Goods Act. ${ }^{113}$ The plaintiff submitted that the contract

107 McNamara, above n 89, 8 .

108 For New Zealand as an example, see McDowell and Webb, above n 35, para 6.3.1.

109 Roder Zelt und Hallenkonstruktionen GmbH v Rosedown Park Pty Ltd [1995] 17 ACSR 153 (FCA).

110 Roder v Rosedown, above n 109, 153, 157-158.

111 Roder v Rosedown, above n 109, 153, 168.

112 Roder v Rosedown, above n 109, 153, 156 line 26-9.

113 Perry Engineering v Bernold [2001] SASC 15. 
between the parties provided that "all matters ... arising directly or indirectly therefrom shall be governed in all respect by the Laws of the State of South Australia..." Nevertheless, Burley J correctly pointed out that the CISG is part of the law of South Australia and hence the CISG and not the Sale of Goods Act was applicable. His Honour then went on to comment that "[t]he statement of claim has been drawn up on the assumption that the South Australian Sale of Goods Act applies. This seems to me to be fatal to the plaintiff's ability to proceed to judgment."114 He used these "deficiencies in the statement of claim" to decline to assess damages as the plaintiff had pleaded.

As these decisions indicate, the lack of persuasive CISG precedents might, therefore, be explained by the parties' or their lawyers' ignorance or unfamiliarity with the CISG. It should, therefore, be highly appreciated when courts make an attempt to draw the attention of the parties to the Convention and its implications. Thus, these cases might serve as both illustration and warning to those who ignore the CISG. ${ }^{115}$

\section{CONCLUSION}

The analysis has shown that the previous paucity of CISG-related case law from common law countries does not result from an inherent incompatibility of the common law with the CISG. Neither the CISG nor the common law system, are, by their very nature, predestined to hamper the further development of CISG-related case law. The recent bloom of reported decisions in the United States seems to support this notion.

The strictness of the traditional literal approach towards statutory interpretation has been eased, in particular in respect to international conventions. Common law courts have finally acknowledged the absence of concepts such as the parol evidence rule or consideration. A concern here is, again, the tendency to import such domestic concepts via Article 4 of the CISG into CISG-related cases and thus displace the provisions of the Convention. Against the background of the precedent system, the United Kingdom's dismissive stance towards the Convention has potentially deprived the common law system of valuable precedents. However, there is a trend towards greater independence from English law in decisions from other common law jurisdictions. Furthermore, common law judges refer to scholarly writing more and more commonly, which promotes the uniform interpretation and application of the Convention. Finally, it should be borne in mind that the scope of available case law is not always precisely reflected by case databases. Overall it seems that the CISG is an established feature in courtrooms of both civil and common law countries, which appears to be better known by courts than by lawyers and parties.

114 Perry Engineering v Bernold, above n 113, paras 15-17.

115 See editorial remarks by Bruno Zeller on Perry Engineering $v$ Bernold <http://www.cisg.law.pace. edu/cisg/wais/db/cases2/010201a2.html> (last accessed 21 May 2004). 
Any shortfalls of the acceptance of the CISG to date should not obstruct the view of its advantages. The great merit of the CISG is that it removes a substantial barrier to international trade by providing a unified and simplified legal framework within which international sales can operate. One can assume that for each reported court decision on a database, there are many more disputes which were resolved in another manner or which have not been reported. Moreover, there surely is an even larger number of international transactions that fell within the scope of the CISG in which no dispute arose at all. No matter what the outcome is, the Convention provides a common legal basis and, thus, legal certainty, for any transaction it governs.

However, the legal certainty provided by the Convention is not and presumably never will be a one-way supply. The interpretation and, consequently, the appropriate application of the Convention largely benefits from extrinsic input provided by courts, scholars, lawyers, travaux preparatoires, and commentaries. It is a reciprocal system of knowledge transfer operating on a worldwide basis that enhances uniform application of the Convention and that, lastly, will make the CISG shine. Lawyers in particular can contribute to this knowledge transfer by abandoning their reservations and apply and plead the CISG more frequently where it is appropriate, or at least where it is required. This is not only limited to dispute resolution but also applies to contract negotiations and drafting.

Lawyers might object that it is too much to ask of them to spend their valuable time in search for scarce resources on the CISG, to look for obscure cases from foreign countries just to end up before a judge who has either never heard of the CISG or takes the first exit out of it; and all this just to make a contribution to general CISG know-how. However, as this article has tried to demonstrate, this situation is increasingly unlikely to occur. Nobody asks lawyers to engage with the CISG for its own sake. But where the parties can benefit from it or where the Convention is applicable, counsel should not hesitate to use it. In this case, they are not left alone with some kind of inscrutable piece of text. There are numerous excellent and instantly available sources on the Internet, which provide an exhaustive range of cases, scholarly writings and commentaries on every major and most minor issues arising from the CISG. Finally, courts, including those in common law countries, have shown a significant willingness to apply the CISG and to arrive at reasonable and just solutions under its regime. Thus, the author's appeal to all members of the legal profession is: Go out, familiarise yourself with the Convention, and use it! 
